\title{
Economic Literacy Among Social Studies Teachers in Oman
}

\author{
Ahmed Al-Rabaani \\ Associate Professor, Social Studies Curriculum \& Instruction, Sultan Qaboos University - College of \\ Education, Omani Studies Center
}

\begin{abstract}
The study investigates economic literacy among Omani teachers of social studies. An economic literacy test was used consisting of 36 questions distributed into five sections: monetary policies, global currencies, global economic clusters, countries with highest natural resources production, and countries with highest GDP and individual income. The test was applied to 661 male and female social studies teachers from five governorates in Oman. The results showed that the teachers had a moderate level of economic literacy, which was significantly affected by their gender and experience. The study recommends the importance of enhancing the level of social studies teachers' economic literacy.
\end{abstract}

Keywords: Economic literacy, Social studies, Teachers, Schools, Oman, GCC

DOI: $10.7176 / \mathrm{JEP} / 10-4-05$

\section{Introduction \\ Background}

A sound economic foundation is essential to drive development in any part of the world, thus it receives intense attention from governments, companies and individuals. The direct effects of economic events on politics, business and individuals within states and across borders are clearly visible, often in spectacular failures such as the economic crisis in 2008 or the oil price collapse in 2014. Economic events are massively influential in political, business and individual decisions, sometimes involving strong reactions to economic solutions such as public strikes against monetary policies, inflation and financial crisis.

Dealing with different economic circumstances requires economic literacy among people to apply basic economic concepts in their daily lives, such as a general understanding of the functioning of the economy, markets, goods, tax, inflation, services, work, economic clusters, trade blocs and work. All of these dimensions have direct impacts on every individual's life. The concept of economic literacy was defined by Al Said $(2009,5)$ as "individual understanding of all economic issues at local and regional and global level", and by Girls Inc. (2018) as "the ability to use basic economic concepts to make decisions about earning, saving, spending, and sharing money... a skill. As with reading and writing, a working knowledge of basic economic concepts is essential for future success". It can be concluded that economic literacy is enhancing individual understanding of basic economic concepts, economic behavior and recognition of economic fluctuations.

Economic literacy is curial for the socio-economic development of every country (Dwivedi, 2004). It fosters people understanding of economic roles in the development of their countries and individual contributions within it (Akhan, 2015). It enables people to understand worldwide economic trends and interdependences (Darvin, 2006), and prepares people to interact with different economic matters resulting from changeable political and economic policies (Koshal et al., 2008). In addition, it provides them with the historical background of economic issues and expectations of economic issues that may be confronted in their lives (Huston, 2010; Remund, 2010). Moreover, it enhances people awareness of economic functions, investment and financial policies such tax, interest rates, saving, profits, inflation, competition and markets (Aarab, 2017; Al Ali, 2014; Cole, Sampson, \& Zia, 2011; Shaker, 2001).

Economic literacy intersects numerous academic and policy domains, notably economics, education, and governance. The importance of economic literacy has received extensive attention among educators, who have found a link between it and people's ability to predict economic trends such as inflation (de Bruin et al., 2010; Leung, 2009) and their behavior (Gerardi, Goette, \& Meier, 2013; Smith, McArdle, \& Willis, 2010; Stango \& Zinman, 2009). Moreover, it influences people's choices of their future career (Kember, Hong, \& Ho, 2008; Pasternak, 2005).

Accordingly, fostering economic literacy is curial for any nation to enhance society participation in an economic context. Thus, education systems have paid attention to teaching economic literacy in schools through introducing economic education or financial education curriculum. In other education systems such as in Oman, economic literacy is taught as part of the social studies curriculum. Quality of teaching according to the curriculum depends on the mastery of economic literacy among the curriculum designers and teachers who deliver such academic content in the classroom. Walstad (2001) noted that a high level of subject knowledge is essential for effective teaching; while this in itself is useless, in combination with suitable general teaching skills, it significantly influences student and school success (Vargh, 2004). It also significantly influences the capability of teachers to convey information to their students (Adu, Galloway, \& Olaoye, 2014; Ball, Thames, \& Phelps, 2008; Baumert et 
al., 2010; Chibueze, 2014; Gokcekus, 2000; Hoy, 2004; Kane, Rockoff, \& Staiger, 2008). Riabova (2003) found that teachers with a high level of economic literacy are better able to put their knowledge into practice in their classrooms.

Given the significant importance of economic literacy among teachers for learning outcomes and indeed national and global socio-economic development, this study essentially seeks to address a gap in the literature by investigating the economic literacy of social studies teachers (SSTs) in Oman, who are the responsible for teaching Omani students economic literacy and developing their knowledge and skills in this area. McGowan (2009) stated that if SSTs have a low level of economic literacy, they will not be able to impart economic knowledge to their students or teach such skills in their classes. Studies exploring the economic literacy of SSTs found a moderate level of proficiency, which may be better than expected given the generally qualitative and eponymously 'social' orientation of learning among such professionals (i.e. they typically specialize in subjects such as sociology rather than economics) (Akhan, 2015; Al-Rabaani \& Al-Mikhlafi, 2011; Fagan, 2007; Hindi, 1998).

The current study represents a response to the current trend in Oman toward enhancing Omanis' participation in economic activities and preparing generation to take responsibility for developing national economic life due to the need to diversify the economy away from reliance on oil and gas, as the world attempts to embrace renewable energy sources. This decades-old quest has resulted in governments throughout the GCC adopting aggressive nationalization policies to promote the employment of nationals in the private sector, given a fillip by the collapse of oil prices in 2014. Despite such efforts, there is a noted lack of private enterprise and initiative in the private sector, with most GCC nationals preferring employment in state sector sinecures. To address this inertia, the Oman Vision 2040 focuses on developing people's economic literacy, innovation and initiatives to involve society in economic activities. Building an economically literate society requires having qualified SSTs to take such responsibility of preparing future generations to ensure national survival, as well as socio-economic development.

This study explores the economic literacy of SSTs in Oman using a test exploring five dimensions: monetary policies, global currencies, global economic clusters, countries with highest natural resources production, and countries with highest GDP and individual income

\section{Aim and Objectives}

The overall aim of this study was to examine the level of economic literacy of SSTs in Oman. The specific research objectives were to:

1. Identify Omani social studies teachers' level of economic literacy about monetary policies, global currencies, global economic clusters, countries with highest natural resources production, highest GDP and individual income.

2. Determine if differences exist in Omani social studies teachers' economic literacy relative to the demographic variables of gender and experience.

\section{Methodology \\ Sample}

The participants in this study comprised 661 Omani SSTs who teach in different Omani governorates. A nonprobability sampling technique was used in selecting the sample because of the impracticability of using random sampling for the whole society of SSTs in five different governorates in Oman (Table 1).

Table 1: Distribution of the study sample

\begin{tabular}{llcc}
\hline & & Number & Total \\
\hline \multirow{2}{*}{ Gender } & Male & 427 & \multirow{2}{*}{661} \\
& Female & 233 & \\
\multirow{5}{*}{ Governorates } & Muscat & 106 & \\
& Al-Batinah & 222 & \multirow{2}{*}{661} \\
& Al- Dakiliah & 123 & \\
& Al-Sharqia & 102 & \\
& Al-Daharah & 108 & \\
\hline
\end{tabular}

\section{Instrument}

An economic literacy test (ELT) was used to determine the economic literacy levels of Omani SSTs (relative to demographic characteristics) in five sections concerning monetary policies, global currencies, global economic clusters, countries with highest natural resources production, and countries with highest GDP and individual income. ELT was developed by the researchers based on literature related to economic literacy (Akhan, 2015; AlRabaani \& Al-Mikhlafi, 2011; Hindi, 1998; Varum, Santos, \& Afreixo, 2014; Walstad Walstad, Rebeck, \& Butters, 2013). 


\section{Validity and Reliability}

ELT was validated by a panel of judges to measure its suitability to measure level of social studies awareness of economic literacy, then it was piloted to 32 Omani SSTs. The Cronbach's alpha was .712, which indicates a suitable internal consistency.

\section{Results}

\section{Economic literacy}

The results showed that participants had an average level of economic literacy (69.73). The teachers showed very low level of knowledge about global economic clusters such as European Union Countries, Asia-Pacific Economic Cooperation, IGAD and the European Economic Community (Table 2).

Table 2: Mean and standard deviation (SD)

\begin{tabular}{lcc}
\hline & Mean & SD \\
\hline Monetary policies & 76.81 & 14.170 \\
\hline Global currencies & 75.67 & 19.493 \\
\hline Global economic clusters & 58.11 & 22.540 \\
\hline Countries with highest natural resources production & 71.06 & 24.105 \\
\hline Countries with highest GDP and individual income & 66.98 & 24.848 \\
\hline Total & 69.73 & 12.620 \\
\hline
\end{tabular}

They also showed a moderate level of awareness about monetary policies $(76.81 \%)$. The results of each question showed variation, with a high level of knowledge about VAT, production activities, free market economy, and national budget deficit, and a very low level of knowledge about inflation and investment. The teachers also seem to have moderate awareness of global currencies. The results showed high level of awareness about the Indian Rupee, US Dollar and Euro, but they had low level of knowledge about the currencies of Brazil, the Czech Republic and Morocco.

They also showed moderate economic literacy about countries with the highest national resources production. They were highly aware of countries with high oil production but they had a moderate level of knowledge of countries producing coal, such as the USA or China, which are also major producers of renewable energy. The teachers had moderate knowledge about countries' level of GDP, such the USA and China, and countries with a high level of individual income, such as Qatar.

The following sections explore differences among Omani SSTs' economic literacy relative to demographic variables (gender, experience and qualifications).

\section{Gender}

Table 3 shows the results of t-test examining differences in SSTs' level of economic literacy with regard to gender. The results reveled that there was a significant difference between male and female SSTs in favor of males for the section on monetary policies and of females for the section on countries with the highest national and individual income, while there was no significant difference in other sections.

Table 3: T-test results of SSTs' gender

\begin{tabular}{|c|c|c|c|c|c|c|}
\hline & Gender & Mean & SD & $\mathrm{t}$ & $\mathrm{df}$ & $\begin{array}{c}\text { Sig. } \\
\text { (2-tailed) }\end{array}$ \\
\hline \multirow{2}{*}{ Monetary policies } & Male & 78.17 & 15.04 & 3.482 & 654 & \multirow{2}{*}{$.001 *$} \\
\hline & Female & 74.15 & 12.13 & 3.713 & 556.372 & \\
\hline \multirow{2}{*}{ Global currencies } & Male & 75.96 & 19.83 & .483 & 654 & \multirow{2}{*}{.629} \\
\hline & Female & 75.18 & 19.08 & .489 & 481.999 & \\
\hline \multirow{2}{*}{ Global economic clusters } & Male & 58.00 & 23.24 & .317 & 654 & \multirow{2}{*}{.751} \\
\hline & Female & 58.58 & 21.26 & .326 & 503.203 & \\
\hline \multirow{2}{*}{ Countries of highest natural resources production } & Male & 70.96 & 24.52 & .000 & 654 & \multirow{2}{*}{1.000} \\
\hline & Female & 70.96 & 23.47 & .000 & 484.191 & \\
\hline \multirow{2}{*}{$\begin{array}{l}\text { Countries of highest national and individual } \\
\text { income }\end{array}$} & Male & 63.40 & 26.20 & -5.193 & 654 & \multirow{2}{*}{$.000 *$} \\
\hline & Female & 73.79 & 20.71 & 5.569 & 564.828 & \\
\hline \multirow{2}{*}{ Overall } & Male & 69.30 & 13.41 & 1.194 & 654 & \multirow{2}{*}{.233} \\
\hline & Female & 70.53 & 11.05 & 1.265 & 547.754 & \\
\hline
\end{tabular}

* Significant at the 0.05 level

\section{Experience}

The results indicated that in general there was no significant difference between participants with regard to their 
economic literacy relative to professional experience except in the section on global economic clusters, where the Scheffe test revealed that teachers with more experience are more knowledgeable.

Table 4: One-way ANOVA results of SSTs' experience

\begin{tabular}{|c|c|c|c|c|c|c|}
\hline & & $\begin{array}{c}\text { Sum of } \\
\text { Squares }\end{array}$ & $\mathrm{df}$ & $\begin{array}{c}\text { Mean } \\
\text { Square }\end{array}$ & $\mathrm{F}$ & Sig. \\
\hline \multirow{3}{*}{ Monetary policies } & Between groups & 58.192 & 3 & 19.397 & \multirow{3}{*}{.096} & \multirow{3}{*}{.962} \\
\hline & Within groups & 132466.783 & 657 & 201.624 & & \\
\hline & Total & 132524.975 & 660 & & & \\
\hline \multirow{3}{*}{ Global currencies } & Between groups & 907.894 & 3 & 302.631 & \multirow{3}{*}{.796} & \multirow{3}{*}{.497} \\
\hline & Within groups & 249895.171 & 657 & 380.358 & & \\
\hline & Total & 250803.066 & 660 & & & \\
\hline \multirow{3}{*}{ Global economic clusters } & Between groups & 4906.659 & 3 & 1635.553 & \multirow{3}{*}{3.252} & \multirow{3}{*}{$.021 *$} \\
\hline & Within groups & 330410.201 & 657 & 502.907 & & \\
\hline & Total & 335316.860 & 660 & & & \\
\hline \multirow{3}{*}{$\begin{array}{l}\text { Countries of highest } \\
\text { natural resources } \\
\text { production }\end{array}$} & Between groups & 2184.413 & 3 & 728.138 & \multirow{3}{*}{1.254} & \multirow{3}{*}{.289} \\
\hline & Within groups & 381338.658 & 657 & 580.424 & & \\
\hline & Total & 383523.071 & 660 & & & \\
\hline \multirow{3}{*}{$\begin{array}{l}\text { Countries of highest } \\
\text { national and individual } \\
\text { income }\end{array}$} & Between groups & 2464.721 & 3 & 821.574 & \multirow{3}{*}{1.333} & \multirow{3}{*}{.263} \\
\hline & Within groups & 405039.061 & 657 & 616.498 & & \\
\hline & Total & 407503.782 & 660 & & & \\
\hline \multirow{3}{*}{ Overall } & Between groups & 85.576 & 3 & 28.525 & \multirow{3}{*}{.178} & \multirow{3}{*}{.911} \\
\hline & Within groups & 105032.391 & 657 & 159.867 & & \\
\hline & Total & 105117.967 & 660 & & & \\
\hline
\end{tabular}

* Significant at the 0.05 level

\section{Discussion}

Economics represents the backbone of the development for individuals, companies, governments and nations. It is well known that individuals can make a difference in their national economic and personal investment. Therefore, there is wide attention to foster economic literacy among individuals in order to involve them in economic activities and to enable them to interact with different economic matters. Education is essential to prepare populations for good citizenship behaviors, including active, effective and responsible economic achievement to promote sustainable socio-economic development. The literature clearly indicated the significant role of education in enhancing students' knowledge, skills and behavior (Batty, Collins, \& Odders-White, 2015; Grol, Sent, \& de Vries, 2016; Meyer \& Frey, 2004).

The results of the current study revealed that the Omani SSTs had a moderate level of economic literacy. Such results could be due to a shortage of economic courses in their teacher training programs, in which they study only two related courses about economics and geography. Furthermore, most in-service training programs focus on teaching methods, building assessments tools, and educational technology. The current results can be said to be similar to some of the previous studies conducted on the economic literacy of teachers (Akhan, 2015; AlRabaani \& Al-Mikhlafi, 2011; Fagan, 2007; Hindi, 1998). The current and previous studies raised the issue of teaching economic literacy in schools in general and Oman in particular where the economic literacy of social studies need to be enhanced to ensure that teachers can make a significant difference with their students. Teacher training preparatory and in-service programs should be developed to reach a suitable level of economic literacy, as numerous studies clearly indicated that these programs make difference in teachers' ability to enhance their students' achievement (Butters \& Fischer, 2008; Clotfelter, Ladd \& Vigdor 2010; Hanushek \& Rivkin 2010; Harris \& Sass 2011; Walstad, 2001).

The results also revealed that there are gender differences in teachers' level of economic literacy, with females having a higher level of literacy about countries of highest national and individual income, while male teachers showed a higher level of knowledge about monetary policies, corroborating previous studies (Akhan, 2015; Grimes, Millea, \& Thomas, 2007; Yohanes et al., 2017). Such differences could be attributed to gender-related background and field of interest.

The results also showed that Omani SSTs' levels of experience influenced their economic literacy, affirming previous findings (Grimes, Millea, \& Thomas, 2007). Such results could be due to older teachers being exposed to more economic fluctuation in Oman, experiencing the effects of monetary policies over time and being more concerned with following economic news.

In general, the results revealed need for developing SSTs' economic literacy to enhance the economic literacy of students and subsequent the nation. The current results showed that the teacher preparation programs and in- 
services training need to be developed with more material in the field of economic literacy. Program designers and policymakers need to expediently address this in order to ensure teachers are optimally supported to deliver the best possible economic literacy instruction to their students (Ball, Thames, \& Phelps, 2008; Baumert et al., 2010; Chibueze, 2014; Gokcekus, 2000; Hoy, 2004; Kane, Rockoff, \& Staiger, 2008; Vargh, 2004; Walstad, 2001).

\section{Conclusion and Recommendations}

The study found that the Omani SSTs had moderate economic literacy and that there are some significant differences due to their gender and experience. The results recommended the need to enhance economic literacy through in-services and teacher preparation programs.

\section{Acknowledgement}

I would like to thank all SSTs who participated in the completing the test and all school administrations for their cooperation in recruiting participants.

\section{References}

Aarab, N. (2017). When Economics Become One of Our Education Priorities. Retrieved May 10, 2018, from http://soo.gd/7YD7

Adu, E. O., Galloway, G., \& Olaoye, O. (2014). Teachers' Characteristics and Students' Attitude Towards Economics in Secondary Schools: Students' Perspectives. Mediterranean Journal of Social Sciences, 5(16), 455-462.

Akhan, N. (2015). Economic Literacy Levels of Social Studies Teachers Candidates. World Journal of Education, $5(1), 25-39$

Al Ali, M. (2014). Economic Awareness. Retrieved May 10, 2018, from http://v.ht/ku0L

Al Said, M. (2009). Effect of TV Channels on Families' Values. Egypt: Al-Arabi Publishing and Distributing

Al-Rabaani, A \& Al-Mikhlafi, M. (2011). Sultan Qaboos University Social Studies Students Teacher' Level of Economic Awareness, Journal of Educational \& Pyscholigical Science, 12(4) 285-311.

Ball, D. L., Thames, M. L., \& Phelps, G. (2008). Content Knowledge for Teaching: What Makes It Special? Journal of Teacher Education, 59(5), 389-407.

Batty, M., Collins, J. M., \& Odders-White, E. (2015). Experimental Evidence on The Effect of Financial Education on Elementary School Students' Knowledge, Behavior and Attitudes. Journal of Consumer Affairs, 49(1), 69-96

Baumert, J., Kunter, M., Blum, W., Brunner, M., Voss, T., Jordan, A., Klusman, U., Krauss, S., Neubrarnd, M., \& Tsai, Y.- M. (2010). Teachers' Mathematical Knowledge, Cognitive Activation in the Classroom, and Student Progress. American Educational Research Journal, 47(1), 133-180.

Chibueze, O. (2014). Factors Affecting the Effective Studying of Economics in Secondary Schools in Izzi Local Government Area of Ebonyi State. National Teachers institute Ebonyi State University Study Centre, Abakaliki. Retrieved May 10, 2018, from https://www.academia.edu/10115175

Clotfelter, C. T., Ladd, H. F., \& Vigdor, J. L. (2010). Teacher Credentials and Student Achievement in High School: A Cross-Subject Analysis with Student Fixed Effects. Journal of Human Resources, 45(3), 655-681.

Cole, S., Sampson, T., and Zia, B. (2011). Price or Knowledge: What Drives Demand for Financial Services in Emerging Markets? Journal of Finance, 66(6), 1933-1967.

Darvin, M. W. (2006). Economics Framework for The 2006 National Assessment of Educational Progress. Washington, DC: US Department of Education, National Assessment Governing Board.

De Bruin, B., Vanderklaauw, W. W., Downs, J. S., Fischhoff, B., Butters, R. B., \& Fischer, T. (2008). Establishing State Specific Benchmarks in Economic Education. Journal of Consumer Education, 25, 61-72.

De Bruin, B., Vanderklaauw, W. W., Downs, J. S., Fischhoff, B., Topa, G., \& Armantier, O. (2010). Expectations of Inflation: The Role of Demographic Variables, Expectation formation, and Financial Literacy. Journal of Consumer Affairs, 44(2), 381-402.

Dwivedi, D. N. (2004). Management Economics. $6^{\text {th }}$ edition. London, UK: Martins Press Inc.

Fagan, C. (2007). Economics Knowledge, Attitudes and Experience of Student Teachers in Scotland. Citizenship, Social and Economics Education, 7(3), 175-188.

Gerardi, K., Goette, L., \& Meier, S. (2013). Numerical Ability Predicts Mortgage Default. Proceedings of the National Academy of Science, 110(28), 11267-71.

Girls Inc. (2018). Economic Literacy. Retrieved May 10, 2018, from http://soo.gd/2e8B

Gokcekus, O. (2000). How Do University Students Value Economics Courses? A Hedonic Approach. Applied Economics Letters, 7(8), 493-496.

Grimes, P., Millea, M., \& Thomas, M. (2007). Testing The Economic Literacy of K-12 Teachers: A State-Wide Baseline Analysis. Social Science Research Network. http://dx.doi.org/10.2139/ssrn.962781

Grol, R., Sent, E.- M., \& de Vries, B. (2016). Effects of Economic Classroom Experiments on Economic 
Knowledge and Reasoning in Secondary Education. Thinking Skills and Creativity, 22, 129-141.

Hanushek, E. A., \& Rivkin, S. G. (2010). Generalizations About Using Value-Added Measures of Teacher Quality. American Economic Review, 100(2), 267-271.

Harris, D. N., \& Sass, T. R. (2011). Teacher Training, Teacher Quality and Student Achievement. Journal of Public Economics, 95(7-8), 798-812.

Hindi, A. (1998). Economic Awareness Among Colleges of Education' Students in the Kingdom of Saudi Arabia. Journal of Education of Asuat College, 14(2), 87.

Hoy, A. W. (2004). Self-Efficacy in College Teaching. Essays on Teaching Excellence, 15(7). Retrieved May 10, 2018, from http://soo.gd/iQAr

Huston, S. J. (2010). Measuring Financial Literacy. Journal of Consumer Affairs, 44(2), 296-316.

Kane, T. J., Rockoff, J. E., \& Staiger, D. O. (2008). What Does Certification Tell Us About Teacher Effectiveness? Evidence From New York City. Economics of Education Review, 27(6), 615-631.

Kember, D., Hong, C. \& Ho, A. (2008). Characterizing the Motivational Orientation of Students in Higher Education: A Naturalistic Study in Three Hong Kong Universities. British Journal of Educational Psychology, $78(2), 313-329$.

Koshal, R., Gupta, A., Goyal, A., \& Choudhary, V. (2008). Assessing the Economic Literacy of Indian MBA Students. American Journal of Business, 23(2), 43-51.

Leung, C. (2009). The Demographics of Household Inflation: Perceptions and Expectations. Reserve Bank of New Zealand: Bulletin, 72(2), 34-42.

Meyer, S., \& Frey, B. (2004). Do Business Students Make Good Citizens? International Journal of the Economics of Business, 11, 141-63.

Pasternak, R. (2005). Choice of Institutions of Higher Education and Academic Expectations: The Impact of CostBenefit Factors. Teaching in Higher Education, 10(2), 189-201.

Remund, D. L. (2010). Financial Literacy Explicated: The Case for A Clearer Definition in an Increasingly Complex Economy. Journal of Consumer Affairs, 44(2), 276-295.

Riabova, I. G. (2003). Training the Teacher for the Economic Education of Younger Students. Russian Education and Society, 45(8), 26-35.

Salemi, M. K. (2005). Teaching Economic Literacy: Why, What and How. International Review of Economics Education, 4(2), 46-57.

Shaker, P. (2001). Literacies for Life: To Meet the Demands of Modern Life, Students Need Three Kinds of Literacy - Economics, Social and Emotional and Aesthetic. Educational Leadership, 59(2), 26-29.

Smith, J., Mcardle, J., \& Willis, R. (2010). Financial Decision Making and Cognition in a Family Context. The Economic Journal, 120(548), F363-F380.

Stango, V., \& Zinman, J. (2009). Exponential Growth Bias and Household Finance. Journal of Finance, 64(6), 2807-2849.

Stern, G. (2002). From Pocketbook to Policymaking, Economic Education Matters: Top of the Ninth. Minneapolis, MN: Federal Reserve Bank of Minneapolis. Retrieved May 10, 2018, from http://soo.gd/uFdY

Vargha, L. D. (2004). Buyer Beware! Economics Activities for Middle School Students. The Social Studies, 95(1), 27-32

Varum, C., Santos, E. and Afreixo, V. (2014). Recent Trends and New Evidence in Economic Literacy Among Adults. Journal of Economic and Economic Education Research, 15(2), 187-205.

Walstad, W. B. (2001). Economic Education in U. S. High Schools. Journal of Economic Perspectives, $15(3), 195-$ 210.

Walstad, W. B., \& Rebeck, K. (2001). Test of Economic Literacy. $3^{\text {rd }}$ edition. New York, NY: National Council on Economic Education.

Walstad, W., Rebeck, K \& Butters, R. (2013). Test of Economy Literacy. Washington, DC: United States of America Council for Economic Education.

Yohanes, H., Laurentius, S., \& Hieronymus, P. (2017). The Level of Economic Literacy Towards Economic Teachers Candidates in Yogyakarta, Indonesia. International Journal of Social Sciences \& Educational Studies, 3(4), 73-88. 